\title{
Powiatowe Archiwum Państwowe w Zamościu w latach 1952-2017
}

ABstrakt: Przez blisko 35 lat Archiwum Państwowe w Zamościu było związane organizacyjnie z Archiwum Państwowym w Lublinie. Archiwum w Zamościu utworzono na podstawie rozporządzenia ministra oświaty z dnia 21 VII 1950 r. powołującego 52 oddziały powiatowe wojewódzkich archiwów państwowych. Od 1951 r. oddział przekształcono w Powiatowe Archiwum Państwowe podległe Wojewódzkiemu Archiwum Państwowemu w Lublinie. Na pierwszą dekadę funkcjonowania archiwum w Zamościu przypadł trudny okres organizacji instytucji pod kierownictwem Hipolita Kozioła. Priorytetem była walka o polepszenie warunków bytowych i lokalowych archiwum oraz przejmowanie dokumentacji archiwalnej z przedpola. Od 1962 r. pod kierownictwem Gertrudy Sowińskiej udało się umieścić siedzibę archiwum w specjalnie do tego celu przeznaczonej kamienicy oraz rozwinąć działalność edukacyjno-popularyzacyjną. Na skutek reformy administracyjnej kraju z 1975 r. PAP w Zamościu przekształcono z dniem 1 II 1976 r. w Wojewódzkie Archiwum Państwowe podległe Naczelnemu Dyrektorowi Archiwów Państwowych. Od tego czasu funkcjonuje jako samodzielna jednostka.

SŁowa KLuczowe: Archiwum Państwowe w Lublinie, Archiwum Państwowe w Zamościu, Wojewódzkie Archiwum Państwowe w Lublinie, Wojewódzkie Archiwum Państwowe w Zamościu, Powiatowe Archiwum Państwowe w Zamościu, Wojewódzkie Archiwum Państwowe w Lublinie Oddział Powiatowy w Zamościu, Hipolit Kozioł, Gertruda Sowińska. 
W 2020 r. Archiwum Państwowe w Zamościu będzie obchodzić jubileusz siedemdziesięciolecia istnienia. Do jubileuszu stulecia, obchodzonego w roku bieżącym przez Archiwum Państwowe w Lublinie, poczekać należy jeszcze ponad trzy dekady, jednak nie sposób nie wykorzystać okazji, aby podkreślić historyczne związki łączące oba archiwa. Działalność zamojskiej placówki rozpoczęła się bowiem pod skrzydłami archiwum lubelskiego. Początki były trudne i bardzo typowe: brak odpowiedniego lokalu i wyposażenia, skromne środki finansowe na funkcjonowanie jednostki, brak świadomości społecznej w zakresie zachowania dla potomnych dziedzictwa kulturowego regionu, niekiedy pojawiające się różnice zdań z dyrekcją w centrali. Wbrew przeciwnościom losu przez ponad 35 lat w Zamościu funkcjonowało jedno z czterech archiwów powiatowych, obok Chełma, Kraśnika i Łukowa podległych Wojewódzkiemu Archiwum Państwowemu w Lublinie.

Pomimo bogatej historii miasta źródła dotyczące archiwalnej przeszłości Zamościa są bardzo skromne. Fundator miasta, Jan Zamoyski, u progu kariery politycznej został archiwistą. Zamoyskiemu przypisuje się, że po powrocie ze studiów w Padwie w ciągu trzech lat uporządkował archiwum królewskie i stał się wybitnym znawcą prawa ${ }^{1}$. W okresie staropolskim w Zamościu akta gromadziły cztery duże instytucje, $\mathrm{z}$ których trzy znajdowały się w bezpośredniej zależności od rodu Zamoyskich. Były to: Ordynacja Zamojska, Akademia Zamojska i Kapituła Zamojska². Władze samorządowe przechowywały dokumenty dotyczące praw miasta i jego mieszkańców oraz wszystkich przejawów życia społecznego. Archiwum miejskie znajdowało się do 1811 r. w pomieszczeniach ratusza, przy urzędującym Magistracie oraz Trybunale Zamojskim³ ${ }^{3}$ Rozpoczęcie szeroko zakrojonej modernizacji twierdzy w drugiej dekadzie XIX w. oraz upaństwowienie Zamościa w $1821 \mathrm{r}$. przyczyniły się do upadku funkcji cywilnych miasta oraz spowodowały ich stopniowe wyrugowanie poza centrum (twierdzę).

Podobny los spotkał archiwum miejskie, które przeniesiono do Szczebrzeszyna, skąd w 1843 r. trafiło do Archiwum Akt Dawnych w Lublinie. Po likwidacji archiwum lubelskiego decyzją władz Królestwa Polskiego w 1887 r., akta zamojskie wywieziono do Wilna. Taki stan trwał do 1918 r., kiedy dekretem

1 Por. Z. Spieralski, Jan Zamoyski, Warszawa 1989, s. 62-63; A. Kędziora, Encyklopedia miasta Zamościa, Zamość 2012, s. 797.

265 lat Archiwum Państwowego w Zamościu, red. A. Kędziora, Zamość 2015, s. 9.

3 Wojewódzki Urząd Ochrony Zabytków w Lublinie Delegatura w Zamościu, B. Sroczyńska, Opracowanie rękopisu Mikołaja Potockiego „Zamość i jego instytucje pod względem oświaty, religii i dziejów krajowych", Zamość 1980, mps. 
Rady Regencyjnej z dnia 31 VII $1918 \mathrm{r}^{4}{ }^{4}$ utworzono Archiwum Państwowe w Lublinie. W ramach rewindykacji po I wojnie światowej większość akt miejskich Zamościa trafiła ponownie do Lublina. Pozostała część zamojskiego zasobu znalazła się w archiwach Lwowa i Mińska. Najstarsze akta dotyczące Ordynacji Zamojskiej, Akademii Zamojskiej oraz instytucji religijnych przechowują m.in. Biblioteka Narodowa w Warszawie i archiwa diecezjalne w Lublinie i Zamościu. Późniejsze akta ordynackie trafiły do Archiwum Państwowego w Lubli$n e^{5}$. Archiwalia zamojskie (dokumenty, kartografia, dokumentacja techniczna) znajdują się ponadto w instytucjach dziedzictwa na terenie Rosji, Ukrainy, Białorusi, Austrii, Czech, Szwajcarii i Szwecji.

Mimo wcześniejszych starań lokalnej społeczności ${ }^{6}$ dopiero po zakończeniu II wojny światowej władze państwowe uznały za zasadne utworzenie w Zamościu archiwum, które miało działać w strukturze funkcjonującego w Lublinie Wojewódzkiego Archiwum Państwowego (dalej: WAPL). W dniu 26 V 1950 r. odbyło się spotkanie w Komitecie Powiatowym Polskiej Zjednoczonej Partii Robotniczej w Zamościu, podczas którego przedstawiciel lubelskiego archiwum, dr Franciszek Cieślak, zreferował sprawę organizacji archiwum w Zamościu. Władze partyjne zobowiązały się w ciągu miesiąca zapewnić odpowiedni lokal oraz przedstawić kandydata na stanowisko kierownika placówki ${ }^{7}$ Osobą godną piastowania tego stanowiska okazał się Hipolit Kozioł, historyk-amator, regionalista i pasjonat archiwistyki ${ }^{8}$. Jak się niebawem okazało, to właśnie na jego barkach spoczęła organizacja placówki.

Archiwum w Zamościu uruchomiono na podstawie rozporządzenia ministra oświaty z dnia 21 VII 1950 r. ${ }^{9}$, powołującego 52 oddziały powiatowe wojewódzkich archiwów państwowych. Prace organizacyjne rozpoczęto jednak kilkanaście dni wcześniej, na skutek telegramu skierowanego 2 VII 1950 r. do WAPL przez Naczelnego Dyrektora Archiwów Państwowych Ryszarda Gerbera, w którym polecił przystąpić do organizacji jednostek podległych w Zamościu

Monitor Polski, R. I, 1918, nr 116.

565 lat Archiwum, s. 9.

6 W 1938 r. Komitet Redakcyjny czasopisma „Teka Zamojska” apelował o utworzenie w Zamościu archiwum stanowiącego ostoję dla badaczy regionu. Zob. http://www.zamosciopedia.pl/ index.php/ap-az/item/1321-archiwum-panstwowe, [dostęp 10.08.2018].

765 lat Archiwum, s. 9.

8 Postać Hipotlita Kozioła bliżej przedstawiła G. Sowińska, Hipolit Kozioł 1907-1987, "Archiwariusz Zamojski” (dalej: AZ) t. 1, 2002, s. 5-7.

9 Dziennik Urzędowy Ministra Oświaty z 1950 r., nr 19, poz. 243. 
i Tomaszowie Lubelskim ${ }^{10}$. Organizację zamojskiego Oddziału Powiatowego WAPL H. Kozioł wspominał następująco: „Archiwum tutejsze rozpoczęło swoją działalność 1 sierpnia $1950 \mathrm{r}$. Już w początkach lipca zgłosił się u mnie delegat Wojewódzkiego Archiwum Państwowego Ob. Cieślak Franciszek i zaproponował mi, bym podjął się zorganizowania Archiwum na terenie miasta Zamościa dla powiatu zamojskiego (...)"11.

Najpilniejszym zadaniem powołanego kierownika było poszukiwanie lokalu dla Oddziału Powiatowego WAPL oraz odpowiedniego pracownika na posadę woźnego. Pod koniec lipca udało się znaleźć lokal o powierzchni $25 \mathrm{~m}^{2}$, mieszczący się w prywatnej kamienicy przy ul. Grodzkiej 11 na Starym Mieście. Lokal był początkowo siedzibą zakładu krawieckiego i pozostawał od kilku miesięcy niezagospodarowany. Pomieszczenie było w bardzo złym stanie technicznym i nadawało się do kapitalnego remontu. $Z$ tego powodu żadna instytucja nie decydowała się na jego zagospodarowanie, dlatego kierownik archiwum natychmiast otrzymał przydział na lokal.

Organizacja pracy oddziału nie była łatwiejsza, ponieważ brakowało niemal wszystkiego. W prowadzonej kronice archiwum H. Kozioł pisał:

Dnia 1 sierpnia zasiedliśmy przy pożyczonym stole i na pożyczonych krzesłach i rozpoczęliśmy urzędowanie, nie zdając sobie jeszcze dobrze sprawy od czego zaczynać. Stopniowo zaczęliśmy zagospodarowywać się. Kupiliśmy przenośny piec kaflowy, potem otrzymaliśmy z Wojewódzkiego Archiwum trzy stoły, cztery krzesła i wieszak. W październiku rozpocząłem wędrówki po terenie $\mathrm{w}$ poszukiwaniu akt podworskich, a na terenie miasta - akt miejskich ${ }^{12}$.

Pierwszy rekonesans nie przyniósł oczekiwanego rezultatu. W byłych folwarkach na terenie powiatu zamojskiego nie odnaleziono żadnych akt, natomiast na terenie Zamościa zlokalizowano m. in. akta Rządu Gubernialnego z lat

10 Archiwum Państwowe w Lublinie (dalej: APL), Archiwum Państwowe w Lublinie 19441983, sygn. 22, s. 3, 6. Tomaszowski Oddział Powiatowy WAPL funkcjonował niespełna dwa lata, natomiast gromadzony zasób został przekazany do centrali w Lublinie oraz archiwów powiatowych w Chełmie i Zamościu. Zob. szerzej L. Wyszyńska, Powiatowe Archiwum Państwowe $w$ Tomaszowie Lubelskim (1950-1952), AZ, t. 13, 2014, s. 83-94.

11 Z kroniki Zamojskiego Archiwum, oprac. A. Kędziora, AZ, t. 1, 2002, s. 9-14 (s. 9).

12 Ibidem. 
1810-1874, Magistratu miasta Zamościa z lat 1915-1947 oraz instytucji bankowych, komunalnych i przemysłowych.

Użytkowany lokal archiwum szybko okazał się niewystarczający. Kierownik Kozioł w listopadzie 1950 r. rozpoczął starania o przejęcie sąsiedniego lokalu, w którym mieścił się zakład zegarmistrzowski. W styczniu 1951 r. pomieszczenie o powierzchni $21 \mathrm{~m}^{2}$ zostało przekazane archiwum. Po wybiciu zamurowanego przejścia urządzono w nowym pokoju kancelarię, natomiast w dotychczas zajmowanym pomieszczeniu o większym metrażu - magazyn. Pozyskano do niego regały o łącznej pojemności 70 m.b. półek.

Od 3 do 20 III 1951 r. nastąpiło przejęcie pierwszej serii akt z Prezydium Miejskiej Rady Narodowej w Zamościu, „(...) zdobytych w wielkim trudzie i mozole, zniesionych w większości na własnych grzbietach"13. Równocześnie podejmowano niezbędne zabiegi konserwacyjne, mające doprowadzić akta zachowane w złym stanie do użyteczności. Przejmowano również dokumentację z innych instytucji: Zarządu Klinkierni w Izbicy, szpitala w Szczebrzeszynie, kolejne serie akt Magistratu miasta Zamościa (z lat 1864-1914) oraz akt dawnej Ordynacji Zamojskiej ze Zwierzyńca. Akta te H. Kozioł przekazywał sukcesywnie do WAPL ${ }^{14}$.

Na podstawie dekretu Rady Ministrów z 29 III 1951 r. o archiwach państwowych (Dz. U. z 1951 r. nr 19, poz. 149) zamojski Oddział Powiatowy WAPL przekształcono w Powiatowe Archiwum Państwowe (dalej: PAP) w Zamościu, podległe do 1975 r. WAPL. W 1951 r. zasięg działania PAP obejmował powiaty: biłgorajski, krasnostawski i zamojski. Po likwidacji w 1952 r. PAP w Tomaszowie Lubelskim obszar działania archiwum w Zamościu rozszerzono również na powiat tomaszowski. Kolejna zmiana nastąpiła po utworzeniu w 1955 r. PAP w Kraśniku, pod którego właściwość przeszedł powiat biłgorajski.

Ze względu na niewystarczającą powierzchnię magazynową kierownik H. Kozioł rozpoczął w 1951 r. starania o przydział dodatkowych pomieszczeń. Dwa pomieszczenia o łącznej powierzchni $24 \mathrm{~m}^{2}$ przekazano archiwum w grudniu 1953 r. W następnym roku wyposażono je w regały, dzięki którym można było pomieścić wszystkie zgromadzone akta. Według przeprowadzonego na koniec 1954 r. skontrum, PAP w Zamościu zgromadził 11914 j.a. stanowiących 177,6 m.b., z czego udało się uporządkować 2172 j.a., natomiast 1923 j.a. zinwen-

\footnotetext{
13 Ibidem, s. 10.

14 Ibidem, s. 10-11.
} 
taryzowac ${ }^{15}$. Przeprowadzone w latach 1950-1953 164 kontrole jednostek podległych oraz wizytacje $\mathrm{w}$ terenie ${ }^{16}$ ujawniły tragiczną sytuację przedpola archiwalnego:

(...) Kontrole te przekonały mnie, że działalność powiatowych archiwów rozpoczęła się zbyt późno. Podzbiornice makulatury pochłonęły w latach 1945-1951 olbrzymią masę wartościowych akt podworskich i różnych urzędów. (...) Tak np. akta gminne w Nieliszu wyrzucone zostały do obory na ściółkę, a akta Nadleśnictwa w Tereszpolu (kilka wozów!) zostały spalone w 1945 r. W czasie tych wizytacji stwierdziłem, że olbrzymia większość urzędów i instytucji nie posiadała właściwych pomieszczeń na składnicę akt. Większość pracowników nie przywiązywała żadnej wagi do niepotrzebnych akt dla urzędowania bieżącego i uważała je za zbędne śmiecie $(\ldots)^{17}$.

Sytuację zasobu uregulowało dopiero rozporządzenie Rady Ministrów z dnia 19 II 1957 r. w sprawie państwowego zasobu archiwalnego (Dz. U. z 1957 r. $\mathrm{nr} 12$, poz. 66). Usankcjonowano prawo przyznania archiwom powiatowym możliwości gromadzenia i przechowywania zasobu z terenu ich właściwości. W 1958 r. ustalono, że zasób archiwów państwowych ma obejmować archiwalia szczebla powiatowego i niższego począwszy od XIX w. Dzięki tym zapisom zasób PAP w Zamościu objął m.in. akta miasta Zamościa z lat ok. 1820-1939.

Pod koniec lat 50. Powiatowe Archiwum Państwowe w Zamościu przeprowadzało kilkadziesiąt kontroli rocznie oraz dokonywało rekonesansów składnic makulatury w regionie. Wszystkie te czynności wykonywał osobiście H. Kozioł. Zakres obowiązków kierownika obejmował również wydawanie zgód na brakowanie oraz porządkowanie przyjętego do archiwum zasobu. W $1956 \mathrm{r}$. kierownik Kozioł odprowadził do centrali w Lublinie 352,27 zł uzyskane za przekazanie na makulaturę $30 \mathrm{~m} . b .(1170 \mathrm{~kg})$ niearchiwalnych dokumentów. W 1960 r. archiwum nie przyjmowało dopływów akt ze względu na brak miejsca w magazynach ${ }^{18}$.

15 Archiwum Państwowe w Zamościu (dalej: APZ), Archiwum Państwowe w Zamościu 1950-1983, Spis zdawczo-odbiorczy z lat 1950-1975, poz. 19.

16 Zob. Archiwum Państwowe w Zamościu 1950-1983, poz. 20.

17 Z kroniki, s. 10.

18 Zob. Archiwum Państwowe w Zamościu 1950-1983, poz. 21. 
Od roku 1957 wykazywano w sprawozdaniu liczbę zrealizowanych w archiwum kwerend. W pierwszym roku sprawozdawczym wykonano ich 14, w następnych latach 18 i 21. W latach 1961-1965 wykazano łącznie 420 kwerend, w następnym pięcioleciu - 445, natomiast w latach 1971-1975 już 602 kweren$\mathrm{dy}^{19}$. Było to dowodem wielkiego nakładu pracy ponoszonej przez H. Kozioła, będącego w jednej osobie kierownikiem i archiwistą. Jego zasługą było również przyczynienie się do wzrostu instytucjonalnego znaczenia PAP w Zamościu i regionie. W 1959 r. zorganizowano pracownię naukową. Biorąc jednak pod uwagę powierzchnię i organizację przestrzeni użytkowej archiwum, musiało to być pojedyncze stanowisko przy jednym stoliku. Wśród pierwszych użytkowników był m.in. Michał Marian Pieszko - profesor zamojskich gimnazjów i liceów, poważany historyk i regionalista. Na potrzeby jego badań sprowadzono do archiwum z Biblioteki Narodowej m.in. siedemnastowieczną kronikę Bazylego Rudomicza ${ }^{20}$.

W latach 60. archiwum rozpoczęło również działalność popularyzatorsko-wystawienniczą. Skala przedsięwzięć była skromna i adekwatna do możliwości organizacyjnych kierownika jednostki. Pierwszą w dziejach archiwum wystawę otwarto 20 VI 1957 r. Trwała 14 dni, popularyzując działalność archiwalną. Wernisaż kolejnej wystawy „Zamojszczyzna w afiszach, ogłoszeniach, odezwach i ulotkach" odbył się w siedzibie archiwum 7 VIII 1960 r. i można ją było oglądać przez 72 dni. Wystawy zasobu archiwalnego były również organizowane poza Zamościem: w Krasnymstawie (1958) i Tomaszowie Lubelskim (1964).

$\mathrm{Na}$ początku lat 60 . nastąpiły zmiany na stanowisku kierowniczym PAP w Zamościu. Hipolit Kozioł kierował instytucją do 31 XII 1961 r., po czym zastąpiła go Gertruda Sowińska. Zwiększono również obsadę kadrową. Od 1962 r. w archiwum pracowali: kierownik, archiwista i młodszy archiwista. Największym wyzwaniem dla nowego kierownictwa była poprawa warunków lokalowych. Zabiegi przyniosły rezultat po pięciu latach, kiedy na skutek remontu kamienic przy ul. Lenina (poprzednio i obecnie ul. Grodzka) archiwum relokowano do kamienicy przy ul. Moranda 4, w obrębie zachodniej pierzei Rynku Wodnego. Metraż powierzchni lokalowej wzrósł do $198 \mathrm{~m}^{2}$, jednak nie wiązało się to z widoczną poprawą warunków bytowych. Kamienica była zaniedbana, ponadto nie została w latach 60 . wytypowana do prac konserwatorskich, prowadzonych w obrębie staromiejskich bloków zabudowy. Poważnym zagrożeniem

\footnotetext{
19 Ibidem.

2065 lat Archiwum, s. 10-11.
} 
dla przechowywanej dokumentacji okazały się zagrzybione pomieszczenia, pogarszając i tak nie najlepsze warunki pracy dla pracowników i użytkowników archiwum. W 1973 r. pozyskano dodatkowe pomieszczenie na piętrze kamienicy, lokując w nim część biurową instytucji, natomiast na parterze urządzono dodatkowy magazyn ${ }^{21}$.

Pomimo tragicznych warunków sukcesywnie przyjmowano, opracowywano i ewidencjonowano kolejne akta. Według sprawozdań, w 1960 r. archiwum zgromadziło blisko 250 m.b. akt ${ }^{22}$. W latach 1967-1968 zmikrofilmowano pierwsze zespoły aktowe (prezydia powiatowych rad narodowych w Krasnymstawie, Tomaszowie i Zamościu), kolejne - pod koniec lat 70. Ze względu na trudne warunki lokalowe oraz przeprowadzkę do nowej siedziby, symbolicznie włączono się w obchody ogólnopolskich tygodni archiwalnych. W 1968 r. w ramach III Ogólnopolskiego Tygodnia Archiwów przygotowano przy ul. Moranda 4 ekspozycję i lekcje archiwalne dla szkół. We współpracy z muzeum w Zamościu zaprezentowano wystawy poświęcone okupacji hitlerowskiej na Zamojszczyźnie, Komunistycznej Partii Polski (obie w 1968 r.) oraz ekspozycję „Początki władzy ludowej na Zamojszczyźnie" (1974) ${ }^{23}$.

Nowa rzeczywistość dla archiwum nastała w wyniku reformy administracji państwowej. Ustawą z dnia 28 V 1975 r. (Dz. U. z 1975 r. nr 16, poz. 91) wprowadzono dwustopniowy podział administracyjny kraju, w wyniku którego Zamość został podniesiony do rangi miasta wojewódzkiego. Do nowego podziału administracyjnego dostosowano również sieć archiwalną. Na podstawie Zarządzenia nr 4 Ministra Nauki, Szkolnictwa Wyższego i Techniki z dnia 21 I 1976 r. utworzono sieć archiwów wojewódzkich. W Zamościu na bazie PAP, 1 II 1976 r. powstało Wojewódzkie Archiwum Państwowe (dalej: WAP) podległe bezpośrednio Naczelnemu Dyrektorowi Archiwów Państwowych. Zasięg działania WAP w Zamościu objął teren województwa zamojskiego ${ }^{24}$.

Powołanie WAP w Zamościu było wyrazem uznania władz centralnych dla historycznych tradycji Zamościa i jego aspiracji jako dynamicznie rozwijającego się ośrodka kulturowego, usługowego i gospodarczego, będącego stolicą Zamojszczyzny ${ }^{25}$. Podkreślono to już uchwałą Rady Ministrów nr 139 z dnia 31 V 1974 r.,

${ }^{21}$ Ibidem, s. 11.

22 Archiwum Państwowe w Zamościu 1950-1983, poz. 21.

${ }^{23} 65$ lat Archiwum, s. 11.

${ }^{24}$ Województwo zamojskie zajmowało powierzchnię $6980 \mathrm{~km}^{2}$.

${ }^{25} \mathrm{~W}$ XX w. Zamość kilkakrotnie miał szansę stać się ośrodkiem wojewódzkim. W tym kierunku planowano również rozwój przestrzenno-gospodarczy miasta. Jednak za każdym razem 
kiedy Zamość otrzymał środki centralne na zaplanowaną na okres 1975-1985 renowację Starego Miasta. Dorobek historyczny miasta i regionu, budowany na dziedzictwie rodu Zamoyskich i odrębności kulturowo-gospodarczej Ordynacji Zamojskiej, uzasadniał utworzenie w Zamościu archiwum wojewódzkiego. Dla porównania, nie było to możliwe $\mathrm{w}$ dwóch innych nowo powstałych województwach: bialskopodlaskim i chełmskim, w których funkcjonowały jedynie zamiejscowe oddziały WAPL (siedziby w Radzyniu Podlaskim i Chełmie).

Dyrektorem WAP w Zamościu została dotychczasowa kierownik PAP, Gertruda Sowińska. Zwiększono obsadę personalną jednostki z trzech do ośmiu osób. Zmiany organizacyjne nie wniosły jednak oczekiwanej poprawy warunków lokalowych, co stało się powodem narastających trudności. Kamienica przy ul. Moranda 4 nadal nie zapewniała podstawowych warunków egzystencji, poważnie ograniczając dalsze gromadzenie i udostępnianie materiałów archiwalnych. Pozyskane w latach 1983-1984 dwa pomieszczenia o powierzchni $55 \mathrm{~m}^{2}$ i $35 \mathrm{~m}^{2}$ nie wpłynęły na poprawę sytuacji, dlatego archiwum po 1990 r. zmuszone było wynajmować dodatkowe powierzchnie magazynowe poza swoją siedzibą ${ }^{26}$. Stanu technicznego kamienicy nie poprawił również przeprowadzony w roku 1985 remont elewacji. Maksymalna powierzchnia użytkowa wykorzystywana przez archiwum w kamienicy przy ul. Moranda 4 wyniosła $400 \mathrm{~m}^{2}$, co było wielkością nadal niewystarczającą ${ }^{27}$.

Z problemów lokalowych instytucji zdawały sobie sprawę władze miejskie i wojewódzkie. Wielokrotne apele dyrekcji WAP w Zamościu nie odniosły jednak rezultatów poza planami i obietnicami. Już w latach 70 . na potrzeby archiwum planowano adaptować część pomieszczeń pofortecznego nadszańca północnego

\footnotetext{
na przeszkodzie stała sytuacja polityczno-gospodarcza kraju. Zob. szerzej: APZ, Biuro Planowania Przestrzennego w Zamościu. Spis zdawczo-odbiorczy nr 1, poz. 240; Spis zdawczo-odbiorczy nr 2, poz. 7, 11, 13-17, 23-35, 37, 38; S. Herbst, Zamość, Warszawa 1954, s. 32; W. Ćwik, J. Reder, Lubelszczyzna. Dzieje podziału terytorialnego, podziałów administracyjnych i ustroju władz, Lublin 1977, s. 129; Z. Kramarz, Zamość w trzydziestoleciu powojennym, [w:] Zamość miasto idealne, red. J. Kowalczyk, Lublin 1980, s. 179-223 (s. 180-182); J. Reder, Zamojszczyzna jako stolica regionu, [w:] Czterysta lat Zamościa, red. J. Kowalczyk, Wrocław 1983, s. 157-164; A. Kędziora, op. cit., s. 759; J. Żygawski, Niezrealizowane projekty śródmieścia Zamościa w XIX i XX wieku na podstawie archiwalnych opracowań kartograficznych, „Teka Komisji Urbanistyki i Architektury PAN Oddział w Krakowie", t. 43, 2015, s. 135-155.

${ }^{26}$ Magazyny archiwum znajdowały się m.in. na poddaszu gmachu dawnego seminarium duchownego przy ul. Akademickiej 4, również przy ul. Przemysłowej 4, pl. Wolności 1 i ul. Moranda 6.

2765 lat Archiwum, s. 12.
} 
przy ul. Łukasińskiego $8^{28}$, tzw. kawalera, stojącego w szyi bastionu VI ${ }^{29}$. W 1987 r. opracowano koncepcję adaptacji na potrzeby archiwum gmachu dawnego seminarium duchownego przy ul. Akademickiej 4, do którego zamierzano, na sąsiedniej działce, dobudować obiekt magazynowy ${ }^{30}$. W latach 90. pojawiły się pomysły ulokowania archiwum w zabytkowych kamienicach przy ul. Ormiańskiej 20 i 22, budowy nowej siedziby przy ul. Hrubieszowskiej 69 (zajmowana obecnie nieruchomość) lub przy ul. Podgroble oraz przeniesienia do kamienic przy ul. Ormiańskiej 9 i 11. Żadna z tych koncepcji nie doszła do skutku. W ciągu kolejnych lat problemy lokalowe kilkakrotnie mogły zaważyć na dalszym działaniu instytucji ${ }^{31}$.

Mimo niepowodzeń w poprawie sytuacji lokalowej nieustannie dążono do wzrostu znaczenia archiwum jako instytucji gromadzącej dokumentację historyczną z terenu Zamojszczyzny. Prestiż jednostki podniosło przekazanie w 1975 r. z WAPL dziewiętnastowiecznych akt miasta Zamościa. Pozostałe archiwalia pozostawały jednak w Lublinie. Bardzo liczono na przeniesienie do Zamościa starszych archiwaliów, dotyczących miast oraz instytucji regionu, zwłaszcza akt Ordynacji Zamojskiej. Apelowało o to wielokrotnie lokalne środowisko naukowe, polityczne oraz autorytety, m.in. prof. Jerzy Kowalczyk i prof. Wiktor Zin ${ }^{32}$. Dopiero patowa sytuacja w 1999 r. umożliwiła przeprowadzkę archiwum do zajmowanego obecnie gmachu przy ul. Hrubieszowskiej $69 \mathrm{~A}^{33}$.

Blisko 35-letni okres funkcjonowania zamojskiego archiwum pod zwierzchnictwem Archiwum Państwowego w Lublinie to okres pionierski, a zarazem naj-

${ }^{28}$ Siedziba Zespołu Szkół Ponadgimnazjalnych nr 1 (tzw. Ekonomik).

${ }^{29}$ Koncepcja w ramach planu rewaloryzacji Starego Miasta w Zamościu z lat 1976-1978 autorstwa Andrzeja Piątka i Janusza Macha z Biura Projektów Pracowni Konserwacji Zabytków w Rzeszowie była aktualna do połowy lat 8o. Według zapisów archiwum miało zająć parter budynku, doraźnie również kazamatę lewą. Zob. szerzej: APZ, Biuro Planowania Przestrzennego w Zamościu. Spis zdawczo-odbiorczy nr 2, poz. 45.

${ }^{30}$ Na potrzeby inwestycyjne Archiwum Państwowego w Zamościu zamierzano przeznaczyć cały blok zabudowy xxviI Starego Miasta. Dokumentacja projektowa obiektu (wariant 1) autorstwa W. Bentkowskiego z Pracowni Projektów Pracowni Konserwacji Zabytków w Zamościu znajduje się w zasobie biblioteki Wojewódzkiego Urzędu Ochrony Zabytków w Lublinie Delegatura w Zamościu, nr 1297 (dokumentacja odziedziczona po Ośrodku Badań i Dokumentacji Zabytków w Zamościu).

3165 lat Archiwum, s. 12-13.

32 Ibidem.

${ }^{33}$ Dnia 14 IV 2000 r. prezydent miasta Zamość przekazał w trwały zarząd 8356/17131 część (powierzchnia $1012 \mathrm{~m}^{2}$ ) budynku biurowo-laboratoryjnego przy ul. Hrubieszowskiej 69A, zajmowanej pierwotnie przez Wojewódzki Inspektorat Ochrony Środowiska w Zamościu. 
trudniejszy w dziejach instytucji. Niemniej pozwolił on na krystalizację działalności zamojskiej placówki oraz jej zakres pracy i kompetencje. Dziś obydwa archiwa działają odrębnie, jednak współpracując na polu działalności archiwalnej wypełniają ważną misję, zachowując dziedzictwo kulturowe oraz pielęgnując dla potomnych historię ziem leżących między Wisłą a Bugiem.

\section{Summary}

\section{District State Archives in Zamość in 1950-1975}

For almost 35 years the State Archives in Zamość was organizationally connected with the State Archives in Lublin. The Archives in Zamość was founded on the basis of the Regulation of the Minister of Education of 21 July 1950, which established 52 district branches of provincial state archives. From 1951 the branch was transformed into the District State Archives subordinated to the Provincial State Archives in Lublin. The first decade of its functioning was a difficult period of organizing the institution under the management of Hipolit Kozioł. The struggle for better premises to house the archives, the personnel's living conditions and collecting documentation from various institutions was a priority. From 1962, under the directorship of Gertruda Sowińska, the seat of the Archives was moved to a specially designed house and its education-popularizing activity managed to develop. As a result of the administrative reform of 1975 the District State Archives was transformed into the Provincial State Archives (since 1 February 1976) subordinate to the General Director of the State Archives. Since that time it has functioned as an independent unit.

KEY WORDS: State Archives in Lublin, State Archives in Zamość, Provincial State Archives in Zamość, District State Archives in Zamość, Hipolit Kozioł, Gertruda Sowińska.

\section{Bibliografia}

\section{Źródła drukowane}

Dziennik Urzędowy Ministra Oświaty z 1950 r., nr 19, poz. 243.

Monitor Polski, r. I, 1918, nr 116. 


\section{Literatura}

65 lat Archiwum Państwowego w Zamościu, red. A. Kędziora, Zamość 2015.

Ćwik W., Reder J., Lubelszczyzna. Dzieje podziału terytorialnego, podziałów administracyjnych i ustroju władz, Lublin 1977.

Herbst S., Zamość, Warszawa 1954.

Kędziora A., Encyklopedia miasta Zamościa, Zamość 2012.

Kramarz Z., Zamość w trzydziestoleciu powojennym, [w:] Zamość miasto idealne, red. J. Kowalczyk, Lublin 1980, s. 179-223.

Reder J., Zamojszczyzna jako stolica regionu, [w:] Czterysta lat Zamościa, red. J. Kowalczyk, Wrocław 1983, s. 157-164.

Sowińska G., Hipolit Kozioł 1907-1987, „Archiwariusz Zamojski”, t. 1, 2002, s. 5-7.

Spieralski Z., Jan Zamoyski, Warszawa 1989.

Wyszyńska L., Powiatowe Archiwum Państwowe w Tomaszowie Lubelskim (1950-1952), „Archiwariusz Zamojski”, t. 13, 2014, s. 83-94.

Z kroniki Zamojskiego Archiwum, oprac. A. Kędziora, „Archiwariusz Zamojski”, t. 1, 2002, s. 9-14.

Żygawski J., Niezrealizowane projekty śródmieścia Zamościa w XIX i XX wieku na podstawie archiwalnych opracowań kartograficznych, „Teka Komisji Urbanistyki i Architektury PAN Oddział w Krakowie”, t. 43, 2015, s. 135-155. http://www.zamosciopedia.pl/index.php/ap-az/item/1321-archiwum-panstwowe, [dostęp 10.08.2018]. 